\title{
Author Correction: The prognostic effects of somatic mutations in ER-positive breast cancer
}

Obi L. Griffith (1) 1,2,3,4, Nicholas C. Spies', Meenakshi Anurag5,6, Malachi Griffith1,2,3,4, Jingqin Luo 3,7, Dongsheng $\mathrm{Tu}^{8}$, Belinda Yeo ${ }^{9}$, Jason Kunisaki ${ }^{1}$, Christopher A Miller ${ }^{1,2}$, Kilannin Krysiak (1) 1,2, Jasreet Hundal', Benjamin J Ainscough (10 1, Zachary L. Skidmore ${ }^{1}$, Katie Campbell', Runjun Kumar ${ }^{2}$, Catrina Fronick ${ }^{1}$, Lisa Cook', Jacqueline E. Snider ${ }^{2}$, Sherri Davies (10 2 ${ }^{2}$, Shyam M. Kavuri ${ }^{5,6}$, Eric C. Chang 5,6 , Vincent Magrini ${ }^{1,4,10}$, David E. Larson (1) 1, Robert S Fulton ${ }^{1,4}$, Shuzhen Liu ${ }^{8}$, Samuel Leung ${ }^{8}$, David Voduc ${ }^{8}$, Ron Bose ${ }^{2}$, Mitch Dowsett ${ }^{9}$, Richard K. Wilson 1,3,4, Torsten O. Nielsen ${ }^{8}$, Elaine R Mardis ${ }^{1,3,4,10}$ \& Matthew J. Ellis ${ }^{5,6}$

Correction to: Nature Communications; https://doi.org/10.1038/s41467-018-05914-x; published online 04 September 2018

The original version of this Article contained errors in the depiction of confidence intervals in the NF1 BCSS data illustrated in Fig. $3 \mathrm{~b}$. These have now been corrected in both the PDF and HTML versions of the Article. The incorrect version of Fig. $3 \mathrm{~b}$ is presented below.

Published online: 14 November 2018

Open Access This article is licensed under a Creative Commons Attribution 4.0 International License, which permits use, sharing, adaptation, distribution and reproduction in any medium or format, as long as you give appropriate credit to the original author(s) and the source, provide a link to the Creative Commons license, and indicate if changes were made. The images or other third party material in this article are included in the article's Creative Commons license, unless indicated otherwise in a credit line to the material. If material is not included in the article's Creative Commons license and your intended use is not permitted by statutory regulation or exceeds the permitted use, you will need to obtain permission directly from the copyright holder. To view a copy of this license, visit http://creativecommons.org/licenses/by/4.0/.
\end{abstract}

(C) The Author(s) 2018

\footnotetext{
${ }^{1}$ McDonnell Genome Institute, Washington University School of Medicine, St. Louis 63108, MO, USA. ${ }^{2}$ Department of Medicine, Division of Oncology, Washington University School of Medicine, St. Louis 63110, MO, USA. ${ }^{3}$ Siteman Cancer Center, Washington University School of Medicine, St. Louis 63110, MO, USA. ${ }^{4}$ Department of Genetics, Washington University School of Medicine, St. Louis 63110, MO, USA. ${ }^{5}$ Lester and Sue Smith Breast Center and Dan L. Duncan Cancer Center, Baylor College of Medicine, Houston 77030, TX, USA. ${ }^{6}$ Departments of Medicine and Molecular and Cellular Biology, Baylor College of Medicine, Houston 77030, TX, USA. 7 Division of Biostatistics, Washington University School of Medicine, St. Louis 63110, MO, USA. ${ }^{8}$ Genetic Pathology Evaluation Centre, University of British Columbia, Vancouver V6H 3Z6, Canada. ${ }^{9}$ Institute of Cancer Research, London SM2 5NG, UK. ${ }^{10}$ Present address: Nationwide Children's Hospital and Department of Pediatrics, The Ohio State University College of Medicine, Columbus 43205, OH, USA. These authors contributed equally: Obi L. Griffith, Nicholas C. Spies, Meenakshi Anurag. The original article can be found online at https://doi.org/10.1038/s41467-01805914-x. Correspondence and requests for materials should be addressed to E.R.M. (email: elaine.mardis@nationwidechildrens.org) or to M.J.E. (email: mjellis@bcm.edu)
} 
a
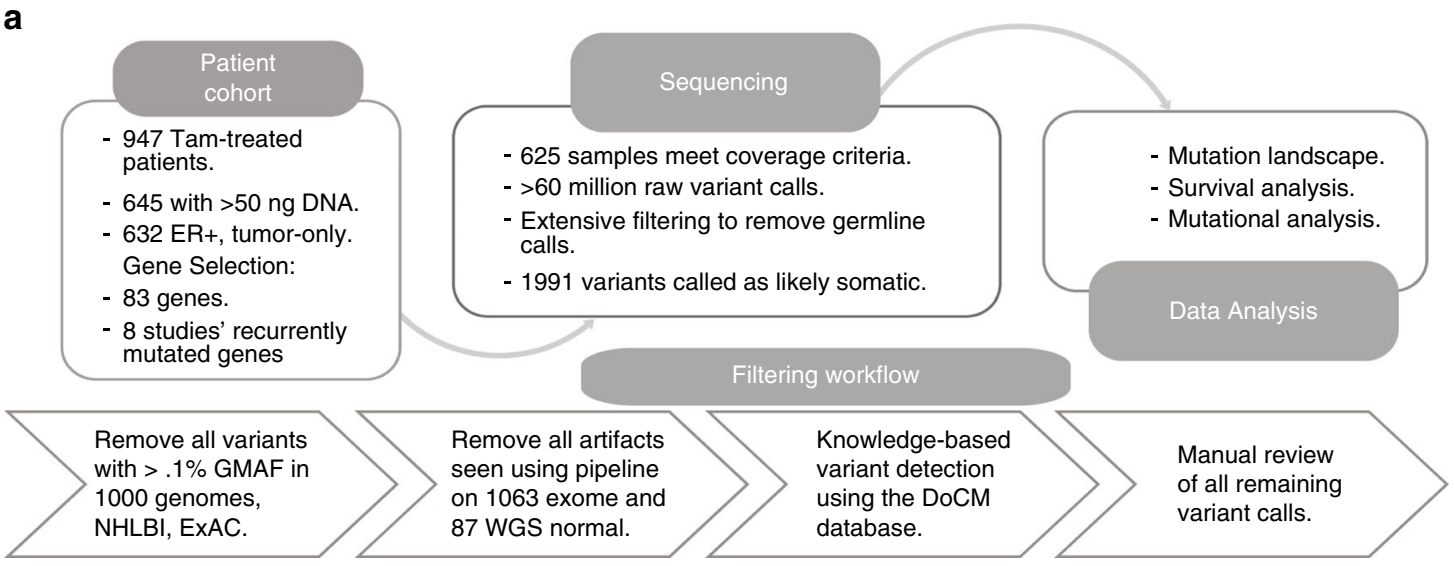

b

Remove all variants
with $>.1 \%$ GMAF in
1000 genomes,
NHLBI, ExAC.

\begin{tabular}{|c|c|c|c|}
\hline Gene & Variant & \#Cases & $p$-value \\
\hline ARID1B & Nonsilent & 30 & $\begin{array}{l}0.1410 \\
0.0310\end{array}$ \\
\hline DDR1 & Nonsilent & 8 & $\begin{array}{r}2.42 \mathrm{E}-05 \\
0.0047\end{array}$ \\
\hline ERBB3 & Nonsilent & 17 & $\begin{array}{l}0.0606 \\
0.0841\end{array}$ \\
\hline MAP3K1 & Nonsilent & 85 & $\begin{array}{l}0.0033 \\
0.0245\end{array}$ \\
\hline $\mathrm{NF} 1$ & $\mathrm{FS} / \mathrm{NS}$ & 7 & $\begin{array}{l}0.1256 \\
0.0167\end{array}$ \\
\hline PIКЗСА & Nonsilent & 285 & $\begin{array}{l}0.0260 \\
0.0349\end{array}$ \\
\hline PRKDC & Nonsilent & 18 & $\begin{array}{l}0.0380 \\
0.0179\end{array}$ \\
\hline TP53 & $\mathrm{FS} / \mathrm{NS}$ & 19 & $\begin{array}{l}0.0288 \\
0.0127\end{array}$ \\
\hline TP53 & Nonsilent & 80 & $\begin{array}{l}0.0216 \\
0.0899\end{array}$ \\
\hline XBP1 & Nonsilent & 14 & $\begin{array}{l}0.0683 \\
0.0593\end{array}$ \\
\hline
\end{tabular}

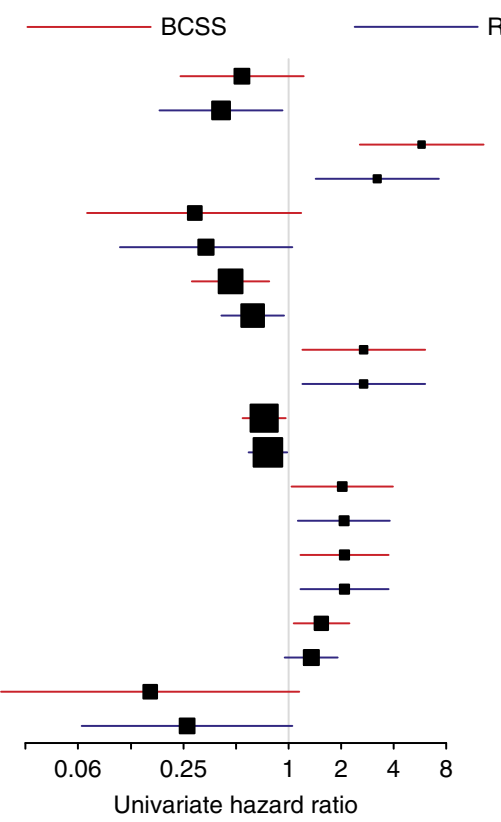

C

$\begin{array}{cccr}\text { Gene } & \text { Variant } & \text { \#Cases } & p \text {-value } \\ \text { ARID1B } & \text { Nonsilent } & 30 & 0.3145 \\ \text { DDR1 } & \text { Nonsilent } & 8 & 0.0000 \\ \text { ERBB3 } & \text { Nonsilent } & 17 & 0.0687 \\ \text { GATA3 } & \text { FS/NS } & 34 & 0.0364 \\ \text { MAP3K1 } & \text { Nonsilent } & 85 & 0.0014 \\ \text { MET } & \text { Nonsilent } & 8 & 0.0859 \\ \text { NF1 } & \text { FS/NS } & 7 & 0.2322 \\ \text { PIK3CA } & \text { Nonsilent } & 285 & 0.0348 \\ \text { PRKDC } & \text { Nonsilent } & 18 & 0.4917 \\ \text { TP53 } & \text { FS/NS } & 19 & 0.0333 \\ \text { TP53 } & \text { Nonsilent } & 80 & 0.0389 \\ \text { Tumor grade } & \text { Clinical } & & 0.0026 \\ \text { Node positivity } & \text { Clinical } & & 0.0000 \\ \text { Tumor size }>5 \mathrm{~cm} & \text { Clinical } & & 0.0000\end{array}$

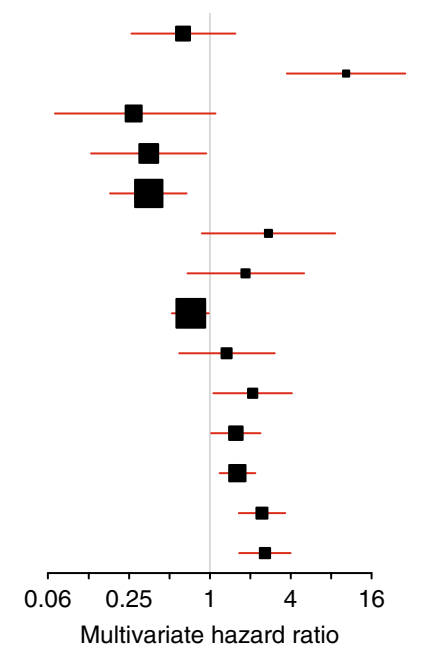

Fig. 3 